\title{
Genotypic Diversity of $S$. mutans in Dental Biofilm Formed In Situ under Sugar Stress Exposure
}

\author{
Rodrigo Alex ARTHUR \\ Cínthia Pereira Machado TABCHOURY \\ Renata de Oliveira MATTOS-GRANER \\ Altair A. DEL BEL CURY \\ Adriana Franco PAES LEME \\ Gláuber Campos VALE \\ Jaime Aparecido CURY
}

School of Dentistry of Piracicaba, State University of Campinas, Piracicaba, SP, Brazil

\begin{abstract}
In situ dental biofilm composition under sugar exposure is well known, but sugar effect on the genotypic diversity of $S$. mutans in dental biofilm has not been explored. This study evaluated $S$. mutans genotypic diversity in dental biofilm formed in situ under frequent exposure to sucrose and its monosaccharide constituents (glucose and fructose). Saliva of 7 volunteers was collected for isolation of S. mutans and the same volunteers wore intraoral palatal appliances, containing enamel slabs, which were submitted to the following treatments: distilled and deionized water (negative control), $10 \%$ glucose $+10 \%$ fructose (fermentable carbohydrates) solution or $20 \%$ sucrose (fermentable and EPS inductor) solution, 8x/day. After 3, 7 and 14 days, the biofilms were colleted and S. mutans colonies were isolated. Arbitrarily primed polymerase chain reaction (AP-PCR) of $S$. mutans showed that salivary genotypes were also detected in almost all biofilm samples, independently of the treatment, and seemed to reflect those genotypes present at higher proportion in biofilms. In addition to the salivary genotypes, others were found in biofilms but in lower proportions and were distinct among treatment. The data suggest that the in situ model seems to be useful to evaluate genotypic diversity of $S$. mutans, but, under the tested conditions, it was not possible to clearly show that specific genotypes were selected in the biofilm due to the stress induced by sucrose metabolism or simple fermentation of its monosaccharides.
\end{abstract}

Key Words: sucrose, genotypes, S. mutans, arbitrarily primed polymerase chain reaction, in situ study.

\section{INTRODUCTION}

Dental caries is a dietary and biofilm-dependent disease related to frequent consumption of fermentable carbohydrates (1) and the low $\mathrm{pH}$ produced by sugar fermentation induces changes in microbiota of dental biofilm (2), selecting the most cariogenic bacteria. Among the dietary sugars, sucrose is considered as the most cariogenic (3) because, in addition to decreasing the $\mathrm{pH}$ of dental biofilm, it is the substrate for the synthesis of extracellular polysaccharides (EPS) (4), which may either promote bacterial adherence to tooth surface (5) during initial colonization or play a role in the cohesiveness of the bacterial communities in the biofilm.
Among the cariogenic bacteria, mutans streptococci (MS) are acidogenic, survive in acidic environments, and produce EPS from sucrose, which make them the most important cariogenic microorganisms (2). However, there is no direct relationship between the exposure to sugars and the MS counts in dental plaque (6-8), suggesting that the changes induced by these microorganisms in dental biofilm are more important than their levels (6). Thus, EPS have been considered virulence factors of the bacteria present in dental biofilm (9) and it has been shown that caries incidence might be more related to the capacity of specific $S$. mutans strains to synthesize insoluble EPS than to their proportions in dental biofilm (10). 
Therefore, some studies have shown that the oral cavity may present distinct genotypes of $S$. mutans, not only in saliva but also in dental biofilm $(11,12)$. Additionally, under frequent sucrose exposure, clinical findings suggest that there was an increase in genotypic diversity of $S$. mutans in the oral cavity (13). These genotypes could present distinct virulence capacities and different abilities of producing EPS (14). Thus, distinct genotypes could be differentiated by their ability to produce insoluble EPS from sucrose, facilitating their adherence to tooth surface, or simply by their predominance in dental biofilm due to a higher capacity to tolerate the acid environment generated by any fermentable sugar. Nevertheless, studies in this direction have been limited to evaluate the absolute MS counts and not the specific genotypes $(7,8)$.

In this context, the in situ model is a recognized experimental design that has been successfully used to evaluate cariogenic dental biofilm formation (3). The biochemical and microbiological composition of dental biofilm has been extensively studied using this model $(4,6-8,15)$. However, the genotypic diversity of $S$. mutans found in dental biofilm formed under exposure to different dietary sugars has not been evaluated.

This research group has hypothesized that genotypes present in saliva would be selectively found in dental biofilm under different stress conditions induced by sugars exposure. Therefore, the purpose of this study was to evaluate $S$. mutans genotypic diversity in dental biofilm formed in situ under frequent exposure to sucrose, a fermentable carbohydrate and inductor of EPS synthesis, and, as control, its monosaccharide constituents, glucose and fructose, which are only fermentable.

\section{MATERIAL AND METHODS}

\section{Experimental Design}

This in situ study, approved by the Ethics in Research Committee of the School of Dentistry of Piracicaba, State University of Campinas, (Protocol \#053/2004), was crossed and double-blinded. Before the beginning of the experiment, stimulated saliva was collected from 12 volunteers to determine the population of mutans streptococci (MS). Seven healthy volunteers (18 to 28 years old), who fulfilled inclusion criteria (counts of mutans streptococci in saliva $\geq 10^{5}$ colony- forming units (CFU) per mL and ability to comply with the experimental protocol) were selected. Salivary isolates of mutans streptococci, showing S. mutans morphological types, were obtained from each volunteer and frozen for subsequent genotyping. Furthermore, the selected volunteers wore acrylic intraoral palatal appliances, containing 6 slabs of sound human dental enamel, which were treated extraorally, 8x/day, with distilled and deionized water (negative control), a mixture of $10 \%$ glucose $+10 \%$ fructose (only acidogenic) or $20 \%$ sucrose solution (acidogenic and EPS inductor) (Merck, Darmstadt, Germany). The biofilm formed onto two enamel slabs was collected after 3, 7 and 14 days of formation, and cultured in Mitis Salivarius Agar (MSA) plus bacitracin (MSB) (Difco, Sparks, MD, USA). S. mutans morphological types present in biofilm samples were isolated and DNA from these isolates, and from those colonies cultured from saliva, was extracted. After this, polymerase chain reaction (PCR) with specific primers was conducted for identification of $S$. mutans, and then, these isolates were submitted to a genotyping protocol by arbitrarily primed PCR (APPCR) with OPA-02 primer.

\section{Saliva Sampling and Selection of Subjects}

A total of 12 healthy adults, who signed a written informed consent form, were screened for salivary levels of MS. Stimulated saliva samples were collected in the morning within fasting condition and without previous teeth brushing. Whole saliva was diluted in sterile $0.9 \% \mathrm{NaCl}$ and plated on MSB to determine MS counts. CFU were counted and the results expressed as $\mathrm{CFU} / \mathrm{mL}$ of stimulated saliva. From that group, a subset of 7 volunteers (18 to 28 years old) was selected (counts of mutans streptococci in saliva $\geq 10^{5} \mathrm{CFU} / \mathrm{mL}$ ). The exclusion criteria were antibiotic use for the last 2 months before starting the study, use of any form of medication that modifies salivary secretion, use of fixed or removable orthodontic appliance, periodontal disease or general/systemic illness. Eight representative morphological types of $S$. mutans colonies were collected from each saliva sample of the selected volunteers, subcultured on MSA and Brain Heart Infusion (BHI) agar (Difco), and pure cultures stored at $-70^{\circ} \mathrm{C}$ in $10 \%$ skim milk medium (Difco) (16) for further genotypic analysis. The purity and identity of the isolates were checked by Gram's staining and colonial morphology 
on MSA.

\section{In Situ Experimental Phases}

An acrylic intraoral palatal appliance containing 6 enamel slabs ( $4 \times 4 \times 2 \mathrm{~mm}$ ) obtained from the buccal and lingual surfaces of sound human impacted third molars, was prepared for each volunteer (4). On the left and right sides of the appliances, 3 cavities of $5 \times 5 \times 3$ mm were made and one slab was placed in each of them, totalizing 3 slabs on each side. Plastic meshes were fixed over the cavities to protect the enamel surfaces from mechanical attrition, leaving a 1-mm space for accumulation of dental biofilm $(4,15)$.

Seven volunteers wore the intraoral appliances during 3 experimental phases of 14 days each and were randomized into 3 different groups. In these groups, the slabs were treated extraorally $8 \mathrm{x} /$ day with: distilled and deionized water (DDW), $10 \%$ glucose $+10 \%$ fructose solution (G+F), and $20 \%$ sucrose solution. The volunteers were instructed to remove the appliances and drip onto the dental slabs one drop of the treatment solutions, at predetermined times. After standing for $5 \mathrm{~min}$, the appliance was replaced in the mouth. The volunteers wore the appliances all the time, removing it for feeding, drinking and oral hygiene (4). All volunteers were subjected to all three treatments, following a doubleblind crossover design. At seven days before the beginning of each treatment and throughout the entire experiment, volunteers used a non-fluoridated dentifrice. Washout periods of 15 days were carried out between each treatment. Because all volunteers were subjected to all treatments, no restriction was made with regard to their diet. The treatment solutions were handed every other day to the volunteers.

\section{Collection of Dental Biofilms}

On the 3rd, 7th and 14th day of each experimental phase, $10 \mathrm{~h}$ after the last exposure to treatments, in the morning and being the volunteers in fasting conditions and without having brushed their teeth, the biofilm formed onto 2 dental slabs selected at random but one from each side of the appliance, was collected. On the 3rd day, biofilm was collected from anterior left and central right slabs; on the 7th day, from central left and posterior right slabs and on the 14th day, from posterior left and anterior right slabs. The biofilm was collected with sterile plastic spatulas, weighed $( \pm 0.01 \mathrm{mg})$ (Ohaus Analytical Plus, Switzerland), suspended in sterile saline(Merck), sonicated (Sonics and Materials, Danbury, CT, USA), serially diluted and inoculated in MSB.

\section{Isolation of S. Mutans Strains and Extraction of Ge- nomic DNA}

Five to eight colonies, representing all morphological types of $S$. mutans, were collected from each saliva and biofilm sample, subcultured on MSA and pure cultures were frozen at $-70^{\circ} \mathrm{C}$ in $10 \%$ skim milk. Then, aliquots were collected from skim milk and plated on BHI agar (Difco), which was incubated for $24 \mathrm{~h}$, at $37^{\circ} \mathrm{C}$ and $10 \% \mathrm{pCO}_{2}$. The colonies from $\mathrm{BHI}$ agar were inoculated into Todd Hewitt Broth (Difco) and incubated for $18 \mathrm{~h}$, at $37^{\circ} \mathrm{C}$ and $10 \% \mathrm{pCO}_{2}$. Cultures were then centrifuged (Jouan, France) at $10,000 \mathrm{~g}, 4^{\circ} \mathrm{C}$ for 15 min, genomic DNA was extracted from the cell pellet, using the Master Pure DNA purification kit(Epicentre Technologies, Madison, WI, USA) (16), and stored at $20^{\circ} \mathrm{C}$. Integrities of the genomic DNA samples were checked in samples electrophoretically resolved in 1\% agarose gel (Invitrogen, Barcelona, Spain) and stained with ethidium bromide $(5 \mu \mathrm{g} / \mathrm{mL})$. Isolates were confirmed for species identity in PCR reactions with primers specific for gtfB, enconding glucosyltransferase B (5'ACTACACTTTCGGGTGGCTTGG-3' and 5'CAGTATAAGCGCCAGTTTCATC-3’)(17)(Invitrogen) and specific to gbpB, enconding glucan-binding protein B (5'-CAACAGAAGCACAACCATCA-3' and 5'TGTCCACCATTACCCCAGT-3') (18). The reactions were performed as described elsewhere $(17,18)$ and the PCR products were analyzed by electrophoresis.

Genotypic Analysis of S. Mutans Isolates by AP-PCR

AP-PCR assays were performed with the arbitrary primer OPA 02 (5'-TGCCGAGCTG-3') (16). The amplifications occurred under the following conditions: $95^{\circ} \mathrm{C}$ for $2 \mathrm{~min}$, for initial denaturation, and 45 cycles of $94^{\circ} \mathrm{C}$ for $30 \mathrm{~s}$ (denaturation), $36^{\circ} \mathrm{C}$ for $30 \mathrm{~s}$ (annealing) and $72^{\circ} \mathrm{C}$ for 1 min (extension) and a final extension at $72^{\circ} \mathrm{C}$ for $5 \mathrm{~min}$. Genomic DNA of S. mutans strain UA 130 (kindly provided by Dr. Page W. Caufield, New York University, NY, USA) and distilled and deionized water were applied in all PCR baths, as positive and negative controls. Products of AP-PCR 
were electrophoretically resolved in $1.5 \%$ agarose gels that were run at $3 \mathrm{~V} / \mathrm{cm}$ during $3 \mathrm{~h}$ in TBE running buffer (16). The gel was stained with a $5 \mu \mathrm{g} / \mathrm{mL}$ of ethidium bromide solution (Invitrogen) for $10 \mathrm{~min}$ and their images captured by a digital imaging system (Gel logic 100 Imaging System, Kodak, Japan).

For analysis of the $S$. mutans genotypic profiles from the same volunteer, AP-PCR products from the isolates obtained from the 3 periods of biofilm formation under the same treatment were always resolved sideby-side in the same gel for visual comparisons (11). Thus, samples representative of each genotype identified per treatment and time were re-run side-by-side in a subsequent gel for direct comparisons of genotypes identified within distinct treatments. Thus, genotypic diversity was compared among isolates from saliva and biofilm samples, obtained from each treatment within the same volunteer. Isolates were considered as having the same genotypic identity when presented identical AP-PCR product-size profiles. The genotypes found were descriptively analyzed and their proportion, in relation to the number of colonies isolated in each sample and condition, was calculated.

\section{RESULTS}

A total of 56 and 469 representative S. mutans colonies were isolated from saliva and biofilms, respectively. In two samples, only 2 representative colonies were isolated from 7-day DDW biofilm (volunteer 5 and 7 ), due to absence of more colonies. All isolates were $S$. mutans identified by PCR and a total of 28 distinct genotypes were identified in the saliva and biofilm samples (Table 1). Figure 1 represents the genotypic diversity found in volunteer 2. In the majority of the volunteers, 6 out of 7, just one genotype was observed in saliva samples, with the exception of volunteer 2, who presented two genotypes in saliva with the prevalence of one of them (Table 1). The same genotypes detected in saliva were identified in the respective biofilm samples, independently of the treatment and period of biofilm formation. On the other hand, in addition to the salivary genotypes, others were found in the biofilm samples exposed to DDW (6 genotypes), G+F (5 genotypes) and sucrose (8 genotypes), which were generally detected in lower proportions (Table 1). Regarding the period of biofilm formation, only a discrete shift occurred in the diversity of genotypes, suggesting a lower diversity in the 14-day biofilm.

\section{DISCUSSION}

Most volunteers showed a predominance of just one genotype in saliva, which was also identified in the biofilms. This agrees with a previous study that evaluated samples of saliva, tongue and biofilm collected from children (12). This finding suggests that saliva samples may reflect at least those genotypes present at higher proportions in teeth biofilms, independent of the conditions in which the biofilm was formed. In addition, the genotypes present in saliva and biofilm samples were distinct among the volunteers (12). As previously mentioned, we hypothesized that salivary genotypes would be selectively found in dental biofilm under different stress conditions induced by sugars exposure, but this hypothesis cannot be either confirmed or rejected due to the low genotypic diversity found in saliva of each volunteer. Thus, the different genotypes found in the biofilms would be originally in the saliva of each volunteer, but below the detection limit of the microbiological method used (11). Nevertheless, the hypothesis reached in the present can be tested because the biofilm was also formed in the absence of sugars exposure. Therefore,

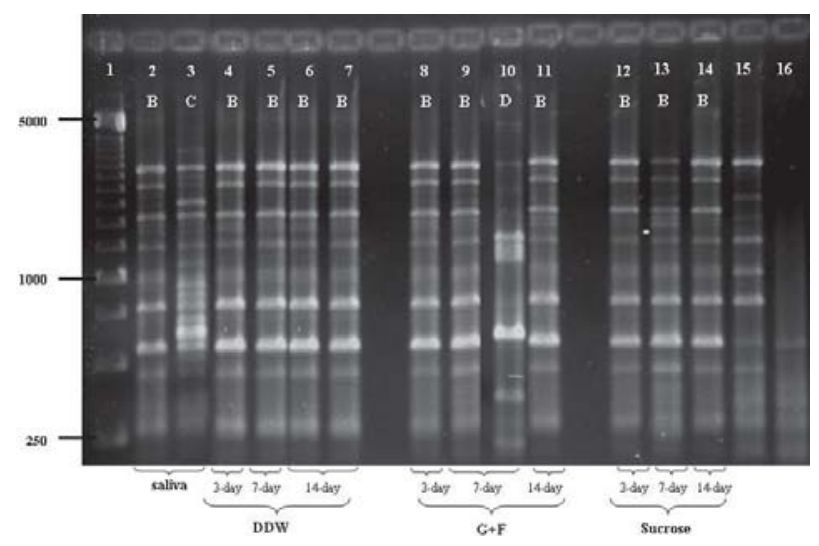

Figure 1. Representative AP-PCR profiles (amplitypes) identified among S. mutans strains isolated from volunteer 2 in saliva and dental biofilm formed under distinct treatments (DDW; G+F and sucrose) and in different periods (3, 7 and 14 days); Lane 1: 250bp DNA ladder; lanes 2 and 3: corresponds to the amplitypes identified in saliva; lanes 4 to 7 correspond to amplitypes identified in DDW biofilm. Lanes 8 to 11: amplitypes identified in G+F biofilm. Lanes 12 to 14: amplitypes identified in sucrose biofilm. Lane 15: AP-PCR profile of the control S. mutans strain UA130. Lane 16: negative control (water). Different letters represent different amplitypes. Biofilm treatments are indicated at the bottom of the figure. 
it was possible to compare the genotypic diversity found in dental biofilm for each volunteer in each evaluation time when biofilm was formed under the tested conditions.

Although the findings were not consistent for all volunteers, Table 1 suggests that different genotypes were selected in the biofilm formed under sugars stress for the volunteers 3, 4, 6 and 7 in comparison with the negative control. Thus, on the 3rd day of biofilm formation in volunteer 4's mouth, the genotypes $\mathrm{M}$ and $\mathrm{N}$ were only found in the sucrose group. Considering that sucrose differs from $\mathrm{G}+\mathrm{F}$ only in insoluble EPS production (4), it is possible that these genotypes produce more EPS than $\mathrm{J}, \mathrm{K}$ and $\mathrm{L}$ found in biofilms formed in presence of $\mathrm{G}+\mathrm{F}$ or in the absence of sugar exposure. The genotypes $\mathrm{M}$ and $\mathrm{N}$ were not the most prevalent in such biofilm, but specific phenotypic characteristics may be more relevant than the relative counts of $S$. mutans (10) or its absolute counts (6). On the 3rd day of biofilm formation under sucrose exposure, it seems that genotypes $\mathrm{W}$ and $\mathrm{Z}$ were also selected in the biofilm of volunteers 6 and 7, respectively. The confirmation of the properties of these genotypes should be conducted, evaluating insoluble EPS production and gtfB expression.

On the 7th day of biofilm formation, genotype $\mathrm{P}$ was found in the biofilm of volunteer 4 only under sucrose exposure. Furthermore, specific genotypes were also found in 7-day and 14-day sucrose biofilms,

Table 1. Genotypic diversity of S. mutans (\%) in saliva and dental biofilm regarding the treatments and time of biofilm formation.

\begin{tabular}{|c|c|c|c|c|c|c|c|c|c|c|}
\hline \multirow[t]{2}{*}{ Volunteer } & \multirow[t]{2}{*}{ Saliva } & \multicolumn{3}{|c|}{3 days } & \multicolumn{3}{|c|}{7 days } & \multicolumn{3}{|c|}{14 days } \\
\hline & & DDW & $\mathrm{G}+\mathrm{F}$ & Sucrose & DDW & $\mathrm{G}+\mathrm{F}$ & Sucrose & DDW & $\mathrm{G}+\mathrm{F}$ & Sucrose \\
\hline 1 & A (100) & NF & A (100) & A (100) & A (100) & A (100) & A (100) & A (100) & A (100) & A (100) \\
\hline 2 & $\begin{array}{l}\text { B (85.7) } \\
\text { C (14.3) }\end{array}$ & B (100) & B (100) & B (100) & B (100) & $\begin{array}{l}\mathrm{B}(40) \\
\mathrm{D}(60)\end{array}$ & B (100) & B (100) & B (100) & B (100) \\
\hline 3 & E (100) & E (100) & E (100) & E (100) & E (100) & $\begin{array}{l}\text { E (83) } \\
\text { F (17) }\end{array}$ & $\begin{array}{l}E(88) \\
G(12)\end{array}$ & E (100) & E (100) & $\begin{array}{c}\text { E (87.5) } \\
\text { H (14.3) }\end{array}$ \\
\hline 4 & I (100) & $\begin{array}{c}\mathrm{I}(62.5) \\
\mathrm{J}(12.5) \\
\mathrm{K}(25.0)\end{array}$ & $\begin{array}{c}\text { I (75) } \\
\text { J (12.5) } \\
\text { L (12.5) }\end{array}$ & $\begin{array}{c}\mathrm{I}(75) \\
\mathrm{M}(12.5) \\
\mathrm{N}(12.5)\end{array}$ & $\begin{array}{c}\text { I (60) } \\
\text { J (20) } \\
\text { O (20) }\end{array}$ & $\begin{array}{l}\text { I (50) } \\
\text { L (50) }\end{array}$ & $\begin{array}{l}\text { I (25) } \\
\text { L(50) } \\
\text { P (25) }\end{array}$ & $\begin{array}{l}\text { I (28.6) } \\
\text { O (71.4) }\end{array}$ & $\begin{array}{l}\text { I (42.9) } \\
\text { J (57.1) }\end{array}$ & I (100) \\
\hline 5 & Q (100) & $\begin{array}{l}\mathrm{Q}(87.5) \\
\mathrm{R}(12.5)\end{array}$ & $\begin{array}{l}\mathrm{Q}(28.6) \\
\mathrm{S}(71.4)\end{array}$ & Q (100) & Q (100) & Q (100) & Q (100) & $\begin{array}{l}\mathrm{Q}(87.5) \\
\mathrm{T}(12.5)\end{array}$ & $\begin{array}{l}Q(87.5) \\
U(12.5)\end{array}$ & Q (100) \\
\hline 6 & V (100) & V (100) & V (100) & $\begin{array}{l}\mathrm{V}(87.5) \\
\mathrm{W}(12.5)\end{array}$ & V (100) & V (100) & V (100) & V (100) & V (100) & V (100) \\
\hline 7 & X (100) & $\begin{array}{l}X(75) \\
Y(25)\end{array}$ & X (100) & $\begin{array}{l}X(87.5) \\
Z(12.5)\end{array}$ & X (100) & X (100) & X (100) & X (100) & $\begin{array}{c}X(87.5) \\
A_{1}(12.5)\end{array}$ & $\begin{array}{l}X(85.7) \\
B_{1}(14.3)\end{array}$ \\
\hline
\end{tabular}

The designation of genotypes by letters (A, B, C, etc) is only valid within each volunteer. Distinct letters show different genotypes. The proportion (\%) of the genotypes in relation to the number of colonies isolated in each condition is represented within the parenthesis. $\mathrm{NF}=\mathrm{S}$. mutans colonies were not found in this sample. DDW = distilled and deionized water group; $\mathrm{G}+\mathrm{F}=$ glucose and fructose solution group. 
as genotypes $\mathrm{G}$ and $\mathrm{H}$ for volunteer 3. Regarding the role of sucrose on biofilm formation, some in situ studies have shown that dental biofilm formed in its presence has high concentrations of insoluble EPS $(4,7,15)$, even after 3 days of formation (8). Insoluble EPS are sticky polysaccharides that could enhance the adherence of $S$. mutans specific genotypes to dental surface (5), which could explain the presence of the described genotypes only in sucrose biofilms.

In addition to these sucrose-specific genotypes, other genotypes were found only in the presence of $G+F$ when compared with sucrose or DDW biofilms within the same volunteer, such as genotype F from 7-day biofilm of volunteer 3 , genotype $U$ from 14-day biofilm of volunteer 5 and genotype $A_{1}$ from 14-day biofilm of volunteer 7 . All these genotypes were less prevalent than the salivary ones. However, other genotypes (genotype $\mathrm{D}$ in 7-day biofilm of volunteer 2 and genotype $\mathrm{S}$ from 3-day biofilm of volunteer 5) were only found in the presence of $\mathrm{G}+\mathrm{F}$, but were more prevalent than the salivary genotypes of each of these volunteers in the biofilm. The fermentation of sucrose or G+F could create an acid condition that influences growth and survival of bacteria (2) and, perhaps, enhances the colonization of more acid tolerant genotypes. In addition, this could explain the finding of genotype $L$ either in presence of G+F or sucrose biofilms of volunteer 4 . The acid tolerant properties of genotypes found later in biofilm formed in presence of sucrose or $\mathrm{G}+\mathrm{F}$ should be evaluated.

There is evidence that $S$. mutans strains, representing distinct AP-PCR patterns, show significant different virulence capacities $(12,14)$ and, this might probably explain the higher ability of sucrose genotypes in producing EPS. Also, these distinct virulence abilities of $S$. mutans genotypes could explain the higher cariogenicity of a biofilm formed in presence of sucrose $(4,8)$, emphasizing that the modifications induced by microorganisms in dental biofilm are more important than their levels in biofilm (6). Therefore, some virulence characteristics of these genotypes should be experimentally explored, which might help explain their distinct colonization.

Regarding the period of biofilm formation, apart from those genotypes that appeared in biofilm selected by sucrose or G+F treatment (as discussed before), no relation between genotypic diversity and aging of dental biofilm was observed in the volunteers, in agreement with (19). However, a direct comparison of our data with other studies is difficult since this was the first one to evaluate genotypic diversity in situ and under experimentally controlled conditions.

Considering some limitations in the reproducibility of the patterns observed (20), the AP-PCR products from the same volunteer at the same treatment and period of biofilm formation were always resolved sideby-side in the same gel and representative samples of each genotype identified per treatment were re-run sideby-side in a subsequent gel for direct comparisons of genotypes identified within distinct treatments. Afterwards, all representative genotypes were submitted to another AP-PCR in order to confirm the pattern of the amplicons.

In summary, the findings of the present study suggest that the genotypes found in saliva seems to reflect those genotypes present at higher proportion in dental biofilms, irrespective of the tested conditions. Moreover, a selection of genotypes could not be observed in dental biofilm formed either or not in the presence of sucrose, but other genotypes, in addition to the salivary ones, were observed in both biofilms, most of them in a lower proportion. Although the phenomenon was not general, it was not possible to show for some volunteers that specific genotypes were selected in the biofilm formed by the stress induced by sucrose metabolism or simply by the fermentation of its monosaccharides.

\section{RESUMO}

A composição do biofilme dental in situ exposto a açúcares ébem conhecida, mas o efeito dos açúcares na diversidade genotípica de S. mutans no biofilme dental ainda não foi explorada. Este estudo avaliou a diversidade genotípica de $S$. mutans no biofilme dental formado in situ sob frequente exposição à sacarose e seus monossacarídeos constituintes (glicose e frutose). Primeiramente, saliva de voluntários foi coletada para isolamento de $S$. mutans e os mesmos voluntários usaram um dispositivo intraoral palatino, contendo blocos de esmalte, que foram submetidos 8x/dia aos seguintes tratamentos: água destilada e deionizada (controle negativo), solução de glicose $10 \%$ + frutose $10 \%$ (carboidratos fermentáveis) e solução de sacarose $20 \%$ (fermentável e indutor de PEC). Após 3, 7 e 14 dias, os biofilmes foram coletados e colônias de $S$. mutans foram isoladas. A técnica de reação em cadeia de polimerase usando primers arbitrários (AP-PCR) demonstrou que o genótipo salivar foi detectado em quase todas as amostras de biofilme, independente do tratamento, e parece refletir aqueles genótipos presentes em maiores proporções no biofilme. Além do genótipo salivar, outros foram encontrados nos biofilmes, mas em uma menor proporção e foram distintos 
entre os tratamentos. Os dados sugerem que o modelo in situ é útil para a avaliação da diversidade genotípica de $S$. mutans. Porém, nas condições do presente estudo, não foi possível demonstrar que genótipos específicos foram detectados no biofilme devido ao estresse induzido pelo metabolismo da sacarose ou fermentação de seus monossacarídeos.

\section{ACKNOWLEDGEMENTS}

The study was supported by CNPq (grant \#470461/2004-7), FAPESP (grant \#03/10972-8 and \#04/11084-1), FAEPEX and FUNCAMP. The authors acknowledge Dr. Alessandra Castro Alves and all the staff of Laboratory of Microbiology and Immunology for their technical support. We also thank the volunteers for their valuable participation.

\section{REFERENCES}

1. Bowen W, Amsbaugh SM, Monell-Torrens S, Brunelle J, Kuzmiak-Jones H, Cole MF. A method to assess cariogenic potential of foodstuff. J Am Dent Assoc 1980;14:24-31.

2. Marsh PD. Are dental diseases examples of ecological catastrophes? Microbiology 2003;149:279-294.

3. Paes Leme AF, Koo H, Belato CM, Bedi G, Cury JA. The role of sucrose in cariogenic dental biofilm formation - new insight. J Dent Res 2006;85:878-887.

4. Cury JA, Rebelo MA, Del Bel Cury AA, Derbyshire MT, Tabchoury CP. Biochemical composition and cariogenicity of dental plaque formed in the presence of sucrose or glucose and fructose. Caries Res 2000;34:491-497.

5. Rölla G. Why is sucrose so cariogenic? The role of glucosyltransferase and polyssacharides. Scand J Dent Res 1989;97:115-119.

6. Cury JA, Francisco SB, Del Bel Cury AA, Tabchoury CPM. In situ study of sucrose exposure, mutans streptococci in dental plaque and dental caries. Braz Dent J 2001;12:101-104.

7. Tenuta LM, Ricomini Filho AP, Del Bel Cury AA, Cury JA. Effect of sucrose on the selection of mutans streptococci and lactobacilli in dental biofilm formed in situ. Caries Res 2006;40:546-549.

8. Vale GC, Tabchoury CPM, Arthur RA, Del Bel Cury AA, Paes Leme AF, Cury JA. Temporal relationship between sucroseassociated changes in dental biofilm composition and enamel demineralization. Caries Res 2007;41:406-412.
9. Bowen WH. Do we need to be concerned about dental caries in the coming millennium? Crit Rev Oral Biol Med 2002;13:126-131.

10. Mattos-Graner RO, Smith DJ, King WF, Mayer MP. Water insoluble glucan synthesis by mutans streptococcal strains correlates with caries in 12 to 30 month old children. J Dent Res 2000;79:1371-1377.

11. Redmo-Emanuelsson IM, Thornqvist E. Distribution of mutans streptococci in families: a longitudinal study. Acta Odontol Scand 2001;59:93-98.

12. Lembo FL, Longo PL, Ota-Tsuzuki C, Rodrigues CR, Mayer MP. Genotypic and phenotypic analysis of Streptococcus mutans form different oral cavity sites of caries-free and caries-active children. Oral Microbiol Immunol 2007;22:313319.

13. Alaluusua S, Mattö J, Grönroos L, Innila S, Torkko H, Asikainem S, Jousimies-Somer H, Saarela M. Oral colonization by more than one clonal type of mutans streptococcus in children with nursing bottle dental caries. Arch Oral Biol 1996;41:67-73.

14. Mattos-Graner RO, Napimoga MH, Fukushima K, Duncan MJ, Smith DJ: Comparative analysis of Gtf isozyme production and diversity in isolates of Streptococcus mutans with different biofilm growth phenotypes. J Clin Microbiol 2004;42:4586-4592.

15. Cury JA, Rebello MAB, Del Bel Cury AA. In situ relationship between sucrose exposure and the composition of dental plaque. Caries Res 1997;31:356-360.

16. Mattos-Graner RO, Li Y, Caufield PW, Duncan M, Smith DJ. Genotypic diversity of mutans streptococci in Brazilian nursery children suggests horizontal transmission. J Clin Microbiol 2001;39:2313-2316.

17. Oho T, Yamashita Y, Shimazaki Y, Kushiyama M, Koga T. Simple and rapid detection of Streptococcus mutans and Streptococcus sobrinus in human saliva by polymerase chain reaction. Oral Microbiol Immunol 2000;15:258-262.

18. Mattos-Graner RO, Jin S, King WF, Chen T, Smith DJ, Duncan MJ. Cloning of the Streptococcus mutans gene encoding glucan binding protein $\mathrm{B}$ and analysis of genetic diversity and protein production in clinical isolates. Infect Immun 2001;69:6931-6941.

19. Redmo-Emanuelsson I, Thornqvist E. Genotypes of mutans streptococci tend to persist in their host for several years. Caries Res 2000;34:133-139.

20. Wullt M, Burman LG, Laurell MH, Akerlund T. Comparison of AP-PCR typing and PCR-ribotyping for estimation of nosocomial transmission of Clostridium difficile. J Hosp Infect 2003;55:124-130. 